\title{
PRELIMINARY PHYTOCHEMICAL SCREENING AND IN VITRO FREE RADICAL SCAVENGING ACTIVITY OF ROOT EXTRACTS OF GLYCYRRHIZA GLABRA L
}

\author{
ARCHANA I, VIJAYALAKSHMI K \\ Department of Biochemistry, Bharathi Women's College, Chennai, Tamil Nadu, India. \\ Viji42research@yahoo.co.in
}

Received: 24 June 2016, Revised and Accepted: 02 July 2016

\begin{abstract}
Objective: Obesity is an international health problem caused by various environmental and genetic factors. Herbal supplements have proved to be active against obesity. Glycyrrhiza glabra belongs to the family of Fabaceae. G. glabra was used traditionally to treat various diseases. Hence, the current study was planned to investigate the phytochemicals and antioxidants present in G. glabra.

Methods: The preliminary qualitative, quantitative phytochemicals, and antioxidants were investigated from the root extracts of G. glabra.

Results: The preliminary qualitative analysis of various extracts of G. glabra showed the presence of phenols, flavonoids, tannins, saponins, and quinones. Quantitative analysis of G. glabra showed elevated amounts of phenols, flavonoids, and tannins in ethanolic extracts. Aqueous, ethanol, hydro-alcoholic extracts of G. glabra showed $211 \pm 2.64,281.66 \pm 1.57,263 \pm 14.2 \mathrm{mg}$ of phenols, $152.66 \pm 3.05,187.33 \pm 1.52,183.33 \pm 3.05 \mathrm{mg}$ of flavonoids, $21.33 \pm 0.57,41 \pm 3.46,34.3 \pm 1.15 \mathrm{mg}$ of Tannins, and $42.33 \pm 2.05,63.33 \pm 1.52,36.33 \pm 1.57 \mathrm{mg}$ of terpenoids. The antioxidant properties of the ethanolic extract of G. glabra were evaluated with the 2,2-diphenyl-1-picryl hydrazyl (DPPH), nitric oxide radical (NO), superoxide radical (SO), hydrogen peroxide radical $\left(\mathrm{H}_{2} \mathrm{O}_{2}\right.$ ), and hydroxyl radical (HO) scavenging activity. The inhibitory concentration $50 \%$ value of G. glabra is $120 \mu \mathrm{g} / \mathrm{ml}$ for $\mathrm{DPPH}, 208 \mu \mathrm{g} / \mathrm{ml}$ for (NO), $196 \mu \mathrm{g} / \mathrm{ml}$ for (SO), $148 \mu \mathrm{g} / \mathrm{ml}$ for $\left(\mathrm{H}_{2} \mathrm{O}_{2}\right.$ ), and $252 \mu \mathrm{g} / \mathrm{ml}$ for (OH). In vitro method suggests that G. glabra is more powerful against nitric oxide and hydroxyl radicals.
\end{abstract}

Conclusion: This preliminary study shows that G. glabra is a promising herb with many phytochemicals and antioxidants and it can be further investigated for its anti-obesity potential.

Keywords: Glycyrrhiza glabra L, Phytochemicals, Antioxidant and obesity.

(C) 2016 The Authors. Published by Innovare Academic Sciences Pvt Ltd. This is an open access article under the CC BY license (http://creativecommons. org/licenses/by/4. 0/) DOI: http://dx.doi.org/10.22159/ajpcr.2016.v9i6.13675

\section{INTRODUCTION}

Obesity can be described as an imbalance between energy intake and expenditure such that excess energy is stored in fat cells, which enlarge or increase in number [1]. There are many different treatments that are used to control obesity including diet, exercise, behavior modification, and medication. Among these treatments, diet and exercises have helped to manage obesity $[2,3]$. Obesity induces oxidative stress, which may be the cause of obesity-related chronic diseases, such as diabetes, hypertension, cardiovascular disease, stroke, asthma, musculoskeletal problems, kidney diseases and certain cancers such as endometrium, ovaries, breast and colon [4,5], gallbladder disease, arthritis, respiratory disease, pregnancy complication, menstrual difficulties and psychological problems [6].

Obesity is a medical condition involving an excess accumulation of body fat. The prevalence of obesity has increased steadily over the last five decades not only in adults but also among children and adolescents [7]. Obesity is also an extremely costly health problem which accounts for $2-6 \%$ of total healthcare costs in developed countries [8]. According to the WHO standards, a body mass index (BMI) of $25.0 \mathrm{~kg} / \mathrm{m}^{2}$ or higher is categorized as overweight; the BMI $30.0 \mathrm{~kg} / \mathrm{m}^{2}$ or more as obese.

Plants play an important role in traditional medicine systems. Numerous preclinical and clinical studies with various herbal medicines reported significant improvement in controlling bodyweight, without any noticeable adverse effects [9]. Various herbal supplements have proved to be active against obesity such as Allium sativum, Citrus aurantium $L$, Cyperus rotundus L, Nelumbo nucifera, Piper nigrum L., Piper longum, and Vitis vinifera L. By literature survey, it is proved that Glycyrrhiza glabra Linn was used traditionally to treat various diseases recently [10]. Hence, this study was selected to evaluate the anti-obesity efficacy of G. glabra.
Licorice (G. glabra $L$ ) belongs to the family Papilionaceae/Fabaceae. It is a traditional medicinal plant that grows in various parts of the world [11]. Phytochemical analysis of G. glabra root extract showed that it contains flavonoids, carbohydrates, saponins, phenols, tannins, terpenoids, and quinones. In the traditional system of medicine, the roots and rhizomes of the G. glabra have been employed clinically for their anti-inflammatory, antiulcer, expectorant, antimicrobial, antioxiolytic, antiallergic, antibacterial, antioxidant, and anti-arthritic activity $[12,13]$. This study was performed to analyze the qualitative, quantitative phytochemicals, and antioxidant investigation of various extracts of G. glabra $L$ was determined.

\section{METHODS}

\section{Collections of plant materials}

The roots of G. glabra $L$ which were collected from the local market and was authenticated by Professor P. Jayaraman, Director, Institute of Herbal Botany, Plant Anatomy Research Centre, Chennai.

\section{Extraction}

The different extracts of dried root powder of G. glabra were prepared using various solvents such as hexane, ethyl acetate, ethanol, hydroalcohol, and aqueous using soxhlet apparatus. The extracts were subjected to rotary evaporator to remove the solvents and then the extract was used for the further analysis.

\section{Phytochemical screening}

The phytochemical screening of the root extracts of G. glabra $L$ was performed using the standard protocol.

\section{Qualitative analysis}

Chemical tests were carried out using standard procedures to identify the constituents as described by Sofowara, Evans, and Harbone [14-16]. 


\section{Quantitative analysis}

\section{Determination of total phenols}

Total phenols were determined by Folin-ciocalteu reagent by the method [17].

\section{Procedure}

About $5 \mathrm{ml}$ of Folin-ciocalteu reagent and $4 \mathrm{ml}$ of aqueous sodium carbonate were added to $0.5 \mathrm{ml}$ of each extract. After 15 minutes incubation at room temperature, the absorbance was read at $765 \mathrm{~nm}$ The standard curve was plotted using chlorogenic acid. Total phenols were expressed in terms of chlorogenic equivalents $(\mathrm{mg} / \mathrm{g})$

\section{Determination of tannin-phenolics}

Tannin - phenolics was determined by the method [18].

\section{Procedure}

Tannins were precipitated by adding either cinchonine sulfate, caffeine, or lead acetate solutions. The concentrations of the reagent required for completely precipitating the tannins were determined earlier. The precipitate containing tannin was dissolved in a known volume of $10 \%$ methanol, and the concentration of tannins was estimated by the Folin-ciocalteu methods. The concentration of tannins was expressed in terms of chlorogenic acid equivalents $(\mathrm{mg} / \mathrm{g})$.

\section{Determination of total flavonoids}

Total flavonoids were determined using the colorimetric method [19].

\section{Procedure}

About $0.5 \mathrm{ml}$ of each extract was mixed with $1.5 \mathrm{ml}$ of methanol, $0.1 \mathrm{ml}$ of $10 \%$ aluminum chloride, $0.1 \mathrm{ml}$ of $1 \mathrm{M}$ potassium acetate, and $2.8 \mathrm{ml}$ of distilled water. It was kept at room temperature for 30 minutes and the absorbance of the reaction mixture was measured at $415 \mathrm{~nm}$. The standard calibration curve was plotted using catechin.

The values were expressed as $\mathrm{mg} / \mathrm{g}$.

\section{Determination of terpenoids}

Terpenoids were estimated according to the method [20].

\section{Procedure}

About $0.2 \mathrm{ml}$ of each extract prepared in ethanol $(\mathrm{mg} / \mathrm{ml})$ was evaporated by keeping it in boiling water bath and to the residue; $0.3 \mathrm{ml}$ of vanilin/glacial acetic acid (W/V) was added. $1 \mathrm{ml}$ of perchloric acid was added and incubated at $60^{\circ} \mathrm{C}$ for 45 minutes. Tubes were cooled in ice and to the mixture, $5 \mathrm{ml}$ of glacial acetic acid was added and the color intensity was measured at $548 \mathrm{~nm}$. The standard curve was plotted using ursolic acid.

The values were expressed as $\mathrm{mg} / \mathrm{g}$.

\section{Assessment of scavenging activity}

Determination of free radical scavenging assay

DPPH (2,2-diphenylpicrylhydrazyl) scavenging activity was determined by the method [21].

\section{Procedure}

The ability to scavenge the stable free radical DPPH is measured by a decrease in the absorbance at $517 \mathrm{~nm}$. To an ethanolic solution of DPPH $(0.05 \mathrm{mM})$, an equal volume of extract dissolved in water was added to a final volume of $1 \mathrm{ml}$. An equal volume of alcohol was added to the control. After 20 minutes, absorbance was recorded at $517 \mathrm{~nm}$ in a UVvisible double beam spectrophotometer. The scavenging activity of the plant extract was calculated using the formula.

$\%$ inhibition $=\left[\left(\mathrm{Abs}_{\text {control }}-\mathrm{Abs}_{\text {sample }}\right) / \mathrm{Abs}_{\text {control }} \times 100\right]$
Where,

$$
\begin{aligned}
& \mathrm{Abs}_{\text {control }}=\text { Absorbance of control } \\
& \mathrm{Abs}_{\text {sample }}=\text { Absorbance of sample }
\end{aligned}
$$

\section{Determination of nitric oxide scavenging activity}

Nitric oxide scavenging activity was measured spectrophotometrically by the method [22].

\section{Procedure}

Sodium nitroprusside (5 $\mathrm{mM})$ in PBS was mixed with different concentrations of the extract dissolved in methanol and incubated at $25^{\circ} \mathrm{C}$ for 150 minutes. The samples from the above were treated with Griess reagent ( $1 \%$ sulfanilamide, $2 \%$ phosphoric acid, $0.1 \%$ naphthyl ethylenediamine dihydrochloride). The absorbance of the chromophore formed during diazotization of nitrite with sulfanilamide and subsequent coupling with naphthyl ethylenediamine hydrochloride was measured at $546 \mathrm{~nm}$ and compared with that of standard solutions treated in the same way.

$\%$ inhibition $=\left[\left(\mathrm{Abs}_{\text {control }}-\mathrm{Abs}_{\text {sample }}\right) / \mathrm{Abs}_{\text {control }} \times 100\right]$

Where,

$\mathrm{Abs}_{\text {. }}=$ Absorbance of control

$\mathrm{Abs}_{\text {sample }}=$ Absorbance of sample

\section{Determination of superoxide anion scavenging activity}

Superoxide anion scavenging activity was carried out by employing NBT reduction assay [23].

\section{Procedure}

A reaction mixture containing $0.4 \mu \mathrm{l}$ of sodium pyrophosphate, $25 \mu \mathrm{l}$ of phenazine methosulfate, $25 \mu \mathrm{l}$ of nitroblue tetrazolium, and $100 \mu \mathrm{l}$ of NADH was mixed with various concentrations of extracts and incubated for $90 \mathrm{~s}$ at $30^{\circ} \mathrm{C}$. Purple colored chromogen formed was measured spectrophotometrically at $560 \mathrm{~nm}$. The scavenging activity of the plant extract was calculated using the formula.

$\%$ inhibition $=\left[\left(\mathrm{Abs}_{\text {control }}-\mathrm{Abs}_{\text {sample }}\right) / \mathrm{Abs}_{\text {control }} \times 100\right]$

Where,

$\mathrm{Abs}_{\text {, }}=$ Absorbance of control

$\mathrm{Abs}_{\text {sample }}=$ Absorbance of sample

\section{Determination of hydroxyl radical scavenging activity}

The scavenging activity of hydroxyl radical was measured by the method [24]

\section{Procedure}

The reaction mixture contained $0.8 \mathrm{ml}$ of phosphate buffer solution ( $50 \mathrm{mmol} / \mathrm{L}, \mathrm{pH} 7.4), 0.2 \mathrm{ml}$ of sample at different concentrations (100$500 \mu \mathrm{g} / \mathrm{ml}), 0.2 \mathrm{ml}$ of EDTA (1.04 mmol/L), $0.2 \mathrm{ml}$ of Fecl3 (1 mmol/L), and $0.2 \mathrm{ml}$ of 2-deoxyribose $(60 \mathrm{mmol} / \mathrm{L})$. The mixture was kept in a water bath at $37^{\circ} \mathrm{C}$ and the reaction was started by adding $0.2 \mathrm{ml}$ of ascorbic acid $(2 \mathrm{mmol} / \mathrm{L})$ and $0.2 \mathrm{ml}$ of $\mathrm{H}_{2} \mathrm{O}_{2}(10 \mathrm{mmol} / \mathrm{L})$. After incubation at $37^{\circ} \mathrm{C}$ for $1 \mathrm{hr}, 2 \mathrm{ml}$ of cold thiobarbituric acid $(10 \mathrm{~g} / \mathrm{L})$ was added to the reaction mixture followed by $2 \mathrm{ml}$ of Hcl (25\%). The mixture was heated at $100^{\circ} \mathrm{C}$ for 15 minutes and then cooled with water Ascorbic acid was used as a standard. The absorbance of solution was measured at $532 \mathrm{~nm}$ with a spectrophotometer. The hydroxyl radical scavenging capacity was evaluated with the inhibition percentage of 2-deoxyribose oxidation of hydroxyl radicals. The scavenging percentage was calculated according to the following formula

$\%$ inhibition $=\left[\left(\mathrm{Abs}_{\text {control }}-\mathrm{Abs}_{\text {sample }}\right) / \mathrm{Abs}_{\text {control }} \times 100\right]$ 
Where,

$\mathrm{Abs}_{\text {control }}=$ Absorbance of control

$\mathrm{Abs}_{\text {sample }}=$ Absorbance of sample

Determination of hydrogen peroxide radical scavenging activity Hydrogen peroxide radical scavenging activity was assayed by the method [25].

\section{Procedure}

The reaction mixture containing $500 \mu \mathrm{l}$ of phosphate buffer and $400 \mu \mathrm{l}$ of $2 \mathrm{mM}$ hydrogen peroxide was mixed with various concentrations of the extract and incubated at room temperature for 5 minutes. Then, $2 \mathrm{ml}$ of dichromate reagent was added and the decrease in color intensity was measured at $570 \mathrm{~nm} .2 \mathrm{ml}$ of dichromate acetic acid reagent alone served as the blank, whereas the reaction mixture without compound served as control.

$\%$ inhibition $=\left[\left(\mathrm{Abs}_{\text {control }}-\mathrm{Abs}_{\text {sample }}\right) / \mathrm{Abs}_{\text {control }} \times 100\right]$

Where,

$\mathrm{Abs}_{\text {control }}=$ Absorbance of control

$\mathrm{Abs}_{\text {sample }}=$ Absorbance of sample

\section{RESULTS AND DISCUSSION}

Phytochemicals screening and determination of phenols, flavonoids, tannins, and terpenoids

Qualitative analysis was carried out in the root extracts of G. glabra and this extracts showed the presence of phytochemical constituents, and the results are summarized in Table 1 . The phytochemical screening of various extracts of G. glabra showed the presence of carbohydrates, flavonoids, saponins, tannins, phlobatannins, terpenoids, glycosides, phenols, alkaloids, quinones, phytosterol, and proteins. It was observed that the preliminary phytochemicals are present in higher amounts in ethanol, hydroalcohol and aqueous extract followed by hexane and ethyl acetate extracts. Hence, further studies were carried out using the aqueous, ethanol and hydro-alcohol extracts.

Table 2 represents the quantitative analysis of the root extracts of G. glabra. The above results showed the presence of total phenols, flavonoids, tannins, and terpenoids. Phenolic compounds are one of the largest and most ubiquitous groups of plant metabolites. They possess biological properties such as antiapoptosis, antiaging, anticarcinogen, anti-inflammation, antiatherosclerosis, cardiovascular protection and improvement of endothelial function, as well as inhibition of angiogenesis and cell proliferation activities [26]. The aqueous, ethanol, and hydro-alcohol extracts showed the presence of the total phenols and were estimated to be $211 \pm 2.64,281.66 \pm 1.57,263 \pm 1.42$ expressed as chlorogenic acid equivalents/g of extracts of the G. glabra.

Secondary chemicals are widely used [27]. It was found that flavonoids help to reduce the blood lipids and glucose in humans. Flavonoid constitute a wide range of substances that play an important role in protecting biological systems against the harmful effects of oxidative processes on macromolecules such as carbohydrates, proteins, lipids and DNA [28]. It belongs to the group of polyphenolic compounds, which are classified as flavones, flavonols, isoflavones, and chalcones. The flavones possess a variety of pharmacological activities including antioxidant, anti-inflammatory, antimicrobial, and anticancer activities. Flavonoids are hydroxylated phenolic substances known to be synthesized by plant in response to microbial infection and the ability to modify the body reactions like allergens [29]. The aqueous, ethanol, hydro-alcohol extracts showed the presence of the flavonoids and were estimated to be $152.66 \pm 3.05,187.33 \pm 1.52,183.33 \pm 3.05$ of Quercetin equivalents/g.

Most of the true tannins are high molecular weight compounds These compounds are complex polyphenols, which are produced by polymerization of simple polyphenols. These are polyphenolic
Table 1: The qualitative analysis of various extract of Glycyrrhiza glabra

\begin{tabular}{llllll}
\hline Compounds & Hexane & $\begin{array}{l}\text { Ethyl } \\
\text { acetate }\end{array}$ & Ethanol & $\begin{array}{l}\text { Hydro } \\
\text { alcohol }\end{array}$ & Aqueous \\
\hline Carbohydrates & - & + & ++ & ++ & +++ \\
Saponins & - & - & + & ++ & +++ \\
Coumarins & - & - & - & - & - \\
Tannins & - & + & +++ & ++ & +++ \\
Phlobatannins & - & + & ++ & + & + \\
Terpenoids & - & ++ & +++ & +++ & + \\
Glycosides & - & + & +++ & ++ & ++ \\
Alkaloids & - & ++ & ++ & ++ & ++ \\
Phenols & - & + & +++ & +++ & +++ \\
Quinones & - & - & +++ & ++ & - \\
Proteins & - & + & ++ & ++ & ++ \\
Flavonoids & - & + & +++ & ++ & ++ \\
Phytosterol & ++ & + & + & + & - \\
\hline
\end{tabular}

+ = Present; ++ = Moderately present; +++ = Present in higher amount; $-=$ Absent

Table 2: Quantitative analysis of Glycyrrhiza glabra

\begin{tabular}{lllll}
\hline S.N & Contents & Aqueous & Ethanol & $\begin{array}{l}\text { Hydro } \\
\text { alcohol }\end{array}$ \\
\hline 1 & Phenols (mg/g) & $211 \pm 2.64$ & $281.66 \pm 1.57$ & $263 \pm 1.42$ \\
2 & Flavonoids (mg/g) & $152.66 \pm 3.05$ & $187.33 \pm 1.52$ & $183.33 \pm 3.05$ \\
3 & Tannins (mg/g) & $21.33 \pm 0.57$ & $41 \pm 3.46$ & $34.3 \pm 1.15$ \\
4 & Terpenoids (mg/g) & $42.33 \pm 2.0$ & $63.33 \pm 1.52$ & $36.33 \pm 1.57$ \\
\hline
\end{tabular}

compounds divided into two main groups, namely hydrolyzed and condensed tannins. Tannins and flavonoids have been shown to have numerous health protective benefits, which includes lowering of blood lipids [30]. Thus, this plant has been used to lower lipid content. Tannins bind to proline-rich protein and interfere with protein synthesis. They are also known to react with proteins to provide the typical tanning effect which is important for the treatment of inflammed or ulcerated tissues. Tannins are a major group of compounds that act as a primary antioxidant or free radicals scavengers and it plays an important role in promoting wound healing process [31]. The aqueous, ethanol, hydroalcohol extracts showed the presence of the tannins and were estimated to be $21.33 \pm 0.57,41 \pm 3.46,34.3 \pm 1.15$ of chlorogenic acid equivalents/g, respectively.

Terpenoids are a large and diverse class of naturally occurring organic chemicals found in all classes of living organisms. Plant terpenoids are used extensively for their aromatic qualities and play a role in traditional herbal remedies. They are currently under investigation by numerous groups for antitumor, antibiotic, anticancer, antineoplastic, antibacterial, anti-inflammatory, and other therapeutic properties [32]. Terpenoids are the most widespread, chemically interesting groups of secondary metabolites with over 30,000 known compounds [33,34]. Many terpenes have biological activities and are used for the treatment of human diseases. The aqueous, ethanol, hydro-alcohol extracts showed the presence of the terpenoids and were estimated to be $42.33 \pm 2.05$, $63.33 \pm 1.52,36.33 \pm 1.57$ of Ursolic acid equivalents/g, respectively. It was observed the ethanolic extract showed high amounts of phenols, flavonoids, tannins, and terpenoids. Hence, further studies were carried out using the ethanolic extract of G. glabra.

\section{In vitro antioxidant activity}

DPPH is a stable free radical and accepts an electron or hydrogen radical to become a stable diamagnetic molecule DPPH radical is usually used as a substrate to evaluate antioxidant activity of antioxidants. It involves reactions of specific antioxidant with stable free radical 2, 2-diphenyl-1-picryl-hyrazyl (DPPH). As a result, there is a reduction of DPPH concentration by the antioxidant, which decreases the optical absorbance of DPPH, and it is detected at $517 \mathrm{~nm}$ [35]. The DPPH radical scavenging effects of G. glabra are presented in Table 3 and Fig. 1. The 
inhibitory concentration ( $\mathrm{IC}_{50}$ ) value of DPPH scavenging activity of the ethanolic extract was found to be $120(\mu \mathrm{g} / \mathrm{ml})$ While the $\mathrm{IC}_{50}$ value for ascorbic acid was $84(\mu \mathrm{g} / \mathrm{ml})$, respectively. The maximum scavenging activity was found to be at $50 \%$ of methanolic extract of P. nigrum Linn. and $\mathrm{IC}_{50}$ value is found to be $189 \mu \mathrm{g} / \mathrm{ml}$ as reported [36].

Nitric oxide radical scavenging procedure is based on the sodium nitroprusside in aqueous solution at physiological $\mathrm{pH}$ spontaneously generates nitric oxide, which interacts with oxygen to produce nitrate ions that can be estimated using Griess reagent. Scavengers of nitric oxide compete with oxygen, leading to reduced production of nitric oxide [22]. The nitric oxide scavenging effects of G. glabra are shown in Table 3 and Fig. 2 . The $\mathrm{IC}_{50}$ value of nitric oxide scavenging activity of ethanolic extract was found to be $208(\mu \mathrm{g} / \mathrm{ml})$ and the $\mathrm{IC}_{50}$ value for ascorbic acid was found to be $192(\mu \mathrm{g} / \mathrm{ml})$, respectively. The maximum scavenging activity was found to be $50 \%$ of ethanolic extract of Centella asiatica and $\mathrm{IC}_{50}$ value was found to be $200 \mu \mathrm{g} / \mathrm{ml}$ [37].

Table 3: IC $_{50}$ value of Glycyrrhiza glabra

\begin{tabular}{llll}
\hline S.N & Free radicals & $\begin{array}{l}\text { IC }_{50} \text { values of ethanolic } \\
\text { extract }(\boldsymbol{\mu g} / \mathbf{m l})\end{array}$ \\
\cline { 3 - 4 } & & $\begin{array}{l}\text { Glycyrrhiza } \\
\text { glabra }\end{array}$ & $\begin{array}{l}\text { Ascorbic } \\
\text { acid }\end{array}$ \\
\hline 1 & DPPH & $120 \pm 2.64$ & $84 \pm 3.21$ \\
2 & Nitric oxide & $208 \pm 1.15$ & $192 \pm 4.35$ \\
3 & Super oxide & $196 \pm 3.51$ & $152 \pm 2.08$ \\
4 & Hydrogen peroxide & $148 \pm 1.52$ & $96 \pm 2.08$ \\
5 & Hydroxyl radical & $252 \pm 1.52$ & $172 \pm 2.51$ \\
\hline
\end{tabular}

DPPH: 2,2-diphenyl-1-picryl hydrazyl, $\mathrm{IC}_{50}$ : Inhibitory concentration

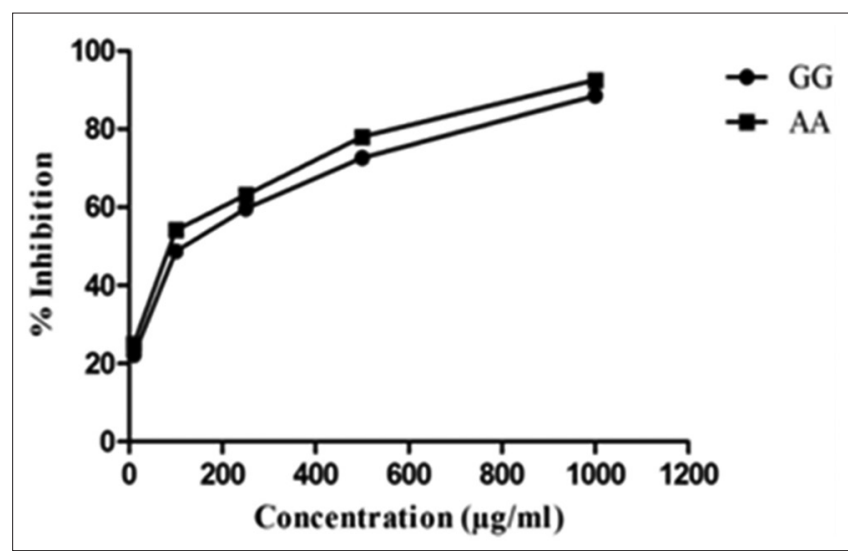

Fig. 1: 2,2-diphenyl-1-picryl hydrazyl radical scavenging activity of ethanolic extract of Glycyrrhiza glabra

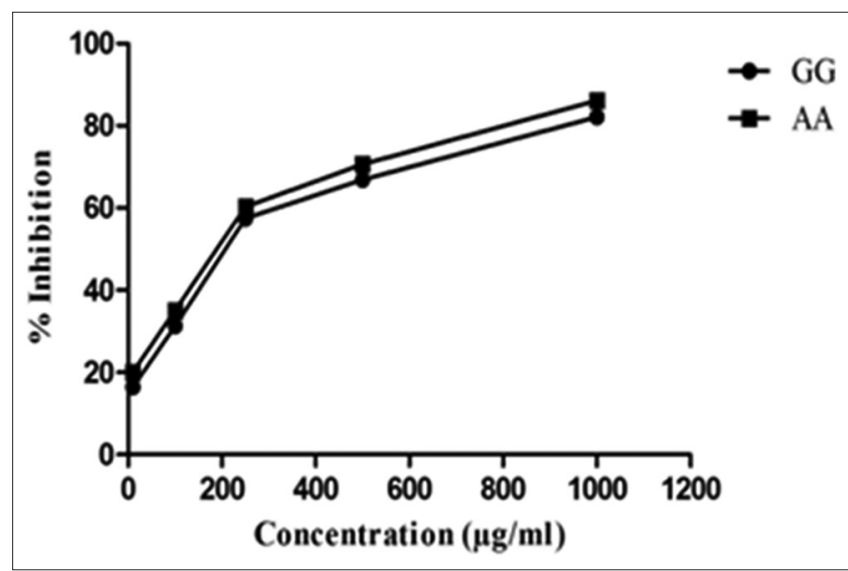

Fig. 2: Nitric oxide radical scavenging activity of ethanolic extract of Glycyrrhiza glabra
Super oxide known to be very harmful to cellular components as a precursor of the more reactive oxygen species is contributed to tissue damage and various diseases. In a biological system, its toxic role can be eliminated by super oxide dismutase. The radicals may also play an important role during the peroxidation of unsaturated fatty acids and other potential susceptible substances [38]. The super oxide scavenging activities of G. glabra are shown in Table 3 and Fig. 3. The $\mathrm{IC}_{50}$ value of super oxide scavenging activity of the extract was found to be $196(\mu \mathrm{g} / \mathrm{ml})$ and the $\mathrm{IC}_{50}$ value for ascorbic acid was $152(\mu \mathrm{g} / \mathrm{ml})$ respectively. The maximum scavenging activity was found to be $50 \%$ of methanolic extract of Hibiscus taiwanensis and the $\mathrm{IC}_{50}$ value was found to be $200 \mu \mathrm{g} / \mathrm{ml}$ [39].

Hydrogen peroxide is a weak oxidizing agent and it is not very reactive, but can cross biological membranes. Because of the possible involvement of hydrogen peroxide in the generation of hydroxyl radicals, hydrogen peroxide becomes very important radical has a more prominent role to initiate cytotoxicity than its chemical reactivity. Thus, removing hydrogen peroxide is very important for the protection of living systems [40]. The hydrogen peroxide scavenging radical effects of G. glabra is shown in Table 3 and Fig. 4 . The $\mathrm{IC}_{50}$ value of hydrogen peroxide scavenging activity of the extract was found to be $148(\mu \mathrm{g} / \mathrm{ml})$ and the $\mathrm{IC}_{50}$ value for ascorbic acid was $96(\mu \mathrm{g} / \mathrm{ml})$, respectively. The maximum scavenging activity was found to be $50 \%$ of methanolic extract of Torilis leptophylla $(L)$ and $\mathrm{IC}_{50}$ value was found to be $130 \mu \mathrm{g} / \mathrm{ml}$ [41].

Hydroxyl radical is the more reactive chemical species known. The hydroxyl radical induces some oxidative damage to biomolecules such as protein, DNA and almost any biological molecule it touches, as food additive to increase the shelf life of foods by preventing lipid

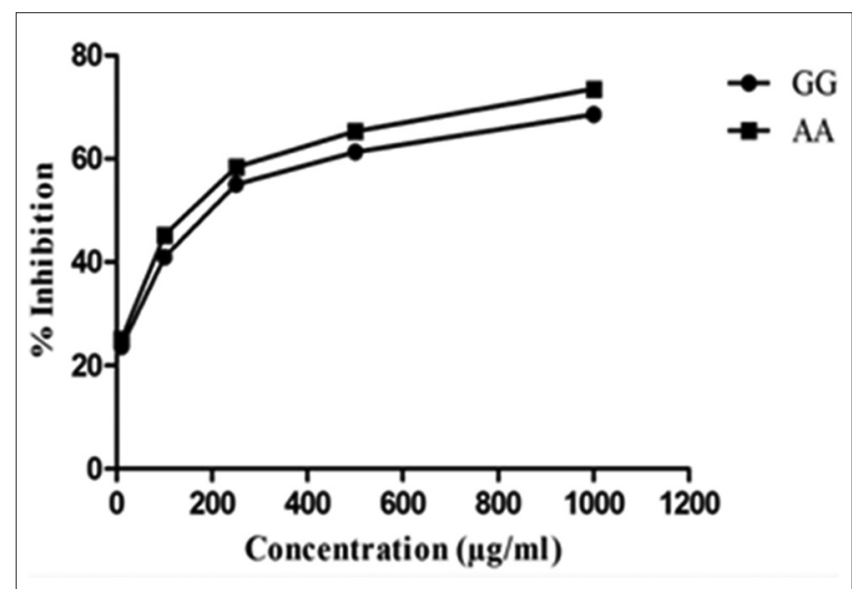

Fig. 3: Super oxide radical scavenging activity of ethanolic extract of Glycyrrhiza glabra

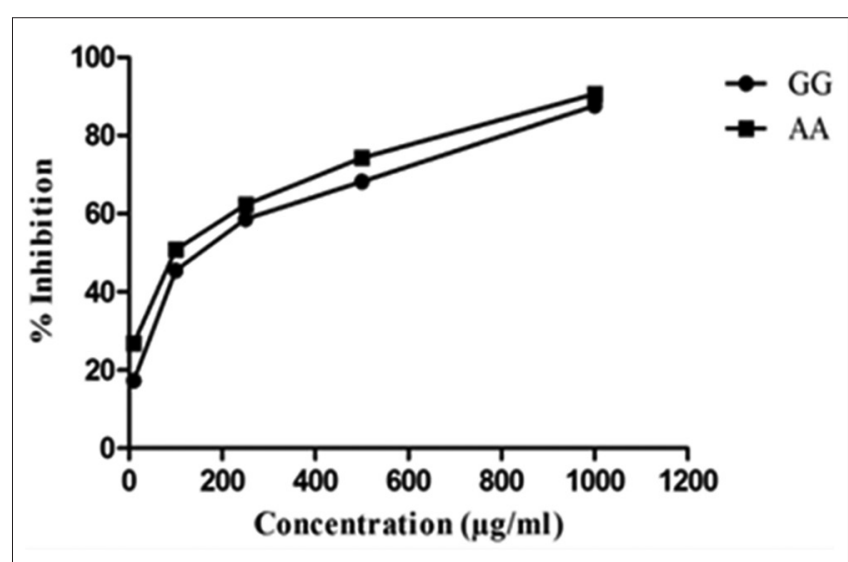

Fig. 4: Hydrogen peroxide scavenging activity of ethanolic extract of Glycyrrhiza glabra 


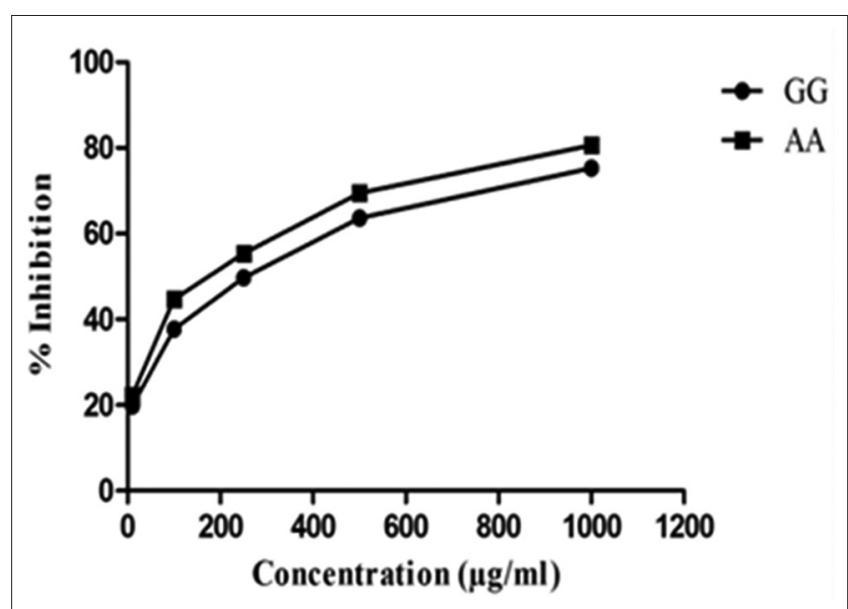

Fig. 5: Hydroxyl radical scavenging activity of ethanolic extract of Glycyrrhiza glabra

peroxidation [42]. Hydroxyl radical scavenging activities of G. glabra are shown in Table 3 and Fig. 5. The $\mathrm{IC}_{50}$ value of hydroxyl radical scavenging activities of the extract was found to be $252(\mu \mathrm{g} / \mathrm{ml})$ and the $\mathrm{IC}_{50}$ value for ascorbic acid was $172(\mu \mathrm{g} / \mathrm{ml})$, respectively. The maximum scavenging activity was found to be $50 \%$ of methanolic extract of Flemingia strobilifera $(L)$ and $\mathrm{IC}_{50}$ value was found to be $337 \mu \mathrm{g} / \mathrm{ml}$ [43].

\section{CONCLUSION}

The phytochemical evaluation can be used for further assessment of secondary metabolites. This investigation will help in further extraction, analysis of compounds from various parts of G. glabra. This study reveals that all the extracts have a significant amount of phytochemicals, especially tannins and flavonoids which contribute to potential health benefits and also acts as a therapeutic agent for obesity. The extracts of the root of G. glabra show the presence of many bioactive secondary metabolites and the ethanolic extract of G. glabra possessed antioxidant potential. It was able to scavenge hydroxyl and nitric oxide radicals very efficiently.

\section{REFERENCES}

1. Achike FI, To NH, Wang H, Kwan CY. Obesity, metabolic syndrome, adipocytes and vascular function: A holistic viewpoint. Clin Exp Pharmacol Physiol 2011;38(1):1-10.

2. Villareal DT, Chode S, Parimi N, Sinacore DR, Hilton T, ArmamentoVillareal R, et al. Weight loss, exercise, or both and physical function in obese older adults. N Engl J Med 2011;364(13):1218-29.

3. Padwal RS, Majumdar SR. Drug treatments for obesity: Orlistat, sibutramine, and rimonabant. Lancet 2007;369(9555):71-7.

4. Rahmouni K, Correia ML, Haynes WG, Mark AL. Obesityassociated hypertension: New insights into mechanisms. Hypertension 2005;45(1):9-14.

5. Van Gaal LF, Mertens IL, De Block CE. Mechanisms linking obesity with cardiovascular disease. Nature 2006;444(7121):875-80.

6. Guelinckz I, Dev lieger R, Mullie P, Vansant G. Effects of lifestyle intervention on dietary habits, physical activity and gestational weight gain in obese pregnant women: A randomized controlled trial, Am J Clin Nutr 2010;91(2):373-80.

7. Manson, JE, Stampfer MJ, Hennekens CH, Willett WC. Body weight and longevity, JAMA 1987;257:353-8.

8. Björntorp P. Obesity. Lancet 1997;350(9075):423-6.

9. Biondi DM, Rocco C, Ruberto G. Dihydrostilbene derivatives from Glycyrrhiza glabra leaves. J Nat Prod 2005;68(7):1099-102.

10. George P, Nimmi OS Cent percent safe centum plants for anti-obesity. Int J Innov Technol Creat Eng 2011;1(3):1-19.

11. Pi-Sunyer X. The medical risks of obesity. Postgrad Med 2009;121(6):21-33.

12. Halade GV, Rahman MM, Williams PJ, Fernandes G. High fat diet- induced animal model of age-associated obesity and osteoporosis J Nutr Biochem 2010;21(12):1162-9.

13. Sofowara A. Medicinal Plants and Traditional Medicines in Africa. Ibadan, Nigeria: Spectrum Books Ltd.; 1993. p. 289.

14. Evans WC. Trease and Evans Pharmacognosy. $14^{\text {th }}$ ed. UK: WB Saunders Company Ltd. 1989. p 1098-115.

15. Harbone JB. Phytochemical Methods. London: Chapman and hall Ltd.; 1973. p.49-88.

16. McDonald S, Prenzler PD, Autolovich M, Robards K. Phenolics content and antioxidant activityof olive extracts. Food Chem 2001;73:73-84.

17. Peri C, Pompei C. Estimation of different phenolic groups in vegetable extracts. Phytochemistry 1972;19:2187-9.

18. Change C, Yang M, Wen H. Estimation of total flavonoids content in propolis by two complementary colorimetric methods, Food Drug Anal 2002;10:178-82.

19. Ing-Luen S, Tzenge-Lien S, Ya-Nang W, Hsin-Tai C, HawFarn L, Han Chien L, et al. Quantification for saponin from a soapberrym (Sapindus makorossi Gaerth) in chaning products by a chromatographic and two calorimetric assay. J Fac Agric Kyushu Univ 2009;54(1):215-21.

20. Koleva II, van Beek TA, Linssen JP, de Groot A, Evstatieva LN. Screening of plant extracts for antioxidant activity: A comparative study on three testing methods. Phytochem Anal 2002;13(1):8-17.

21. Govindarajan R, Rastogi S, Vijayakumar M, Shirwaikar A, Rawat AK, Mehrotra S, et al. Studies on the antioxidant activities of Desmodium gangeticum. Biol Pharm Bull 2003;26(10):1424-7.

22. Chaudhary P, Shukla SK, Kumar IP, Namita I, Afrin F, Sharma RK. Radioprotective properties of apple polyphenols: An in vitro study. Mol Cell Biochem 2006;288(1-2):37-46.

23. Halliwell B, Gutteridge JM, Aruoma OI. The deoxyribose method: A simple "test-tube" assay for determination of rate constants for reactions of hydroxyl radicals. Anal Biochem 1987;165(1):215-9.

24. Sinha AK. Colorimetric assay of catalase. Anal Biochem 1972;47(2):389-94.

25. Han X, Shen T, Lou H. Dietry Polyphenols and their biological significance. Int J Mol Sci 2007;950-88.

26. Bodeker G. Traditional health system: Valuing biodiversity for human health and wellbeing. In: Posey DA, editor. Incultural and Spiritual Values in Biodiversity. Nairobi: Practical Action; 2000. p. 261-84.

27. Atoui AK, Mansouri A, Boskou G, Kefalas P. Tea and herbal infusions: Their antioxidant activity and phenolics profile. Food Chem 2003;89:27-36.

28. Dixon RA, Dey PM, Lamb CJ. Phytoalexins: Enzymology and molecular biologys, Adv Enzymol Relat Areas Mol Biol 1983;55:1-136.

29. Manach C, Scalbert A, Morand C, Rémésy C, Jiménez L. Polyphenols: Food sources and bioavailability. Am J Clin Nutr 2004;79(5):727-47.

30. Polterait $\mathrm{O}$. Antioxidants and free radical scavengers of natural origin. Curr Org Chem 1997;1:410-5.

31. De las Heras B, Rodríguez B, Boscá L, Villar AM. Terpenoids: Sources, structure elucidation and therapeutic potential in inflammation. Curr Top Med Chem 2003;3:171-85.

32. Wang G, Tang W, Bidigare, RR. In: Zhang L, Demain AL, editors. Natural products Drug Discovery and Therapeutic Medicine Terpenoids as Therapeutic Drugs as Pharmaceutical Bulletin. Vol. 50. Humana press $2005 ; 197-227$

33. Umlauf D, Zapp J, Becker H, Adam KP. Biosynthesis of the irregular monoterpene Artemisia ketone, the sesquiterpene germacrene D and other isoprenoid in Tanacetum vulgare L. (Asteraceae). Phytochemistry 2004;65:2463-70

34. Dhalwal K, Deshpande YS, Purohit AP, Kadam SS. Evaluation of the antioxidant activity of Sida cordifolia. Pharm Biol 2005;43(9):754-61.

35. Khalaf NA, Shakya AS, Al-Othman A, El-Agbar Z, Farah H. Antioxidant activity of some common plants. Turk J Biol 2008;32:51-5.

36. Singh D, Mishra M, Gupta N, Singh P, Gupta A, Nema R. Nitric oxide radical scavenging assay of bioactive compounds present in methanol extract of Centella asiatica. Int J Pharm Pharm Sci Res 2012;2(3):42-4

37. Sakanaka S, Tachibana Y, Okada Y. Preparation and antioxidant properties of extracts of Japanese persimmon leaf tea (kakinoha-cha). Food Chem 2005;89:569-74.

38. Lie-Fen S, Jieh-Hen T, Je-Hsin C, Chih-Yang C, Chiu- Ping L. Antioxidant properties of extracts from medicinal plants popularly used in Taiwan. Int J App Sci Eng 2005;3(3):195-202.

39. Van Wijk R, Van Wijk EP, Wiegant FA, Ives J. Free radicals and lowlevel photon emission in human pathogenesis: State of the art. Indian J 
Exp Biol 2008;46(5):273-309.

40. Saeed N, Khan MR, Shabbir M. Antioxidant activity, total phenolic and total flavonoid contents of whole plant extracts Torilis leptophylla L. BMC Complement Altern Med 2012;12:221.

41. Juntachote $\mathrm{T}$ and Berghofer E. Antioxidative properties and stability of ethanolic extracts of Holybasil and Galangal. Food Chem 2005;92:193-202.

42. Madan S, Singh GN, Kumar Y, Kohli K. Phytochemical analysis and free - Radical scavenging activity of Flemingia strobilifera (Linn) $\mathrm{R} \mathrm{Br}$. Res J Pharm Biolo Chem Sci 2010;1(4):183. 